\title{
TAXONOMICAL, MORPHOLOGICAL, ECOLOGICAL AND CHOROLOGICAL NOTES ON OXYBASIS CHENOPODIOIDES AND O. RUBRA (CHENOPODIACEAE) IN ITALY
}

\author{
Duilio IAMONICO ${ }^{1}$
}

\begin{abstract}
On the basis of floristic surveys, examination of herbarium specimens and review of literature, notes on the taxonomy, morphology, and ecological features are given of Oxybasis chenopodioides and morphologically fairly similar Oxybasis rubra. Their distributions in Italy according to Provinces are discussed and mapped.

Key words: Amaranthaceae, Chenopodium, distribution, Italy, new records.

\section{Izvleček}

Na podlagi florističnih raziskav, proučevanj herbarijskih primerkov in pregleda literature smo podali opombe k taksonomiji, morfologiji in ekologiji vrste Oxybasis chenopodioides in morfološko zelo podobne Oxybasis rubra. Prikazali in obravnavali smo njihovo razširjenost v provincah Italije.

Ključne besede: Amaranthaceae, Chenopodium, razširjenost, Italija, novi podatki.
\end{abstract}

\section{INTRODUCTION}

The genus Chenopodium L. s. lat. has a worldwide distribution, and it includes about 150-200 species (Western Australian Herbarium 1998-2009, Mosyakin \& Clemants 2002, 2008, Zhu et al. 2003, Verloove \& Lambinon 2006, APG III 2009, Fuentes-Bazan et al. 2012a). It is considered taxonomically critical because of the morphological variability and lack of good characters and, to some extent, hybridization. Recent molecular studies clearly show that the genus in its widest sense is polyphyletic resulting in six independent lineages (Kadereit et al. 2003, 2005, FuentesBazan et al. 2012a, 2012b). Consequently, a new taxonomic classification of the Chenopodioideae Burnett was proposed (Fuentes-Bazan et al. 2012a), including four tribes (Atriplicae Duby, Anserineae Dumort., Dysphaniae Pax, Axyridae G. Kadereit \& Sukhor.) and ten genera (Axyris L., Blitum L., Ceratocaarpus L., Chenopodiastrum S. Fuentes, Uotila \& Borsch, Chenopodium L., Dys- phania R. Br., Krascheninnikovia Gueldenst., Lipandra Moq., Oxybasis Kar. \& Kir., Teloxys Moq.).

The genus Oxybasis was resurrected to accomodate the Chenopodium species with branched stem, leaves not in basal rosette, inflorescence in not fleshy glomerules and usually dimorphic flowers with 3-5 tepals and horizontal and vertical seeds (Fuentes-Bazan et al. 2012a, Sukhorukov 2013). Four European and Italian taxa (Iamonico 2012b) are included in the genus: O. glauca (L.) S. Fuentes, Uotila \& Borsch (三 Chenopodium glaucum L.), O. urbica (L.) S. Fuentes, Uotila \& Borsch (EChenopodium urbicum L.), O. chenopodioides (L.) S. Fuentes, Uotila \& Borsch (= Chenopodium botryodes Sm.), O. rubra (L.) S. Fuentes, Uotila \& Borsch (三 Chenopodium rubrum L.).

Oxybasis chenopodioides and O. rubra represent a critical pair of species having fairly similar gross morphology, even though they do not seem to be close relatives (see e.g. Fuentes-Bazan 2012a). Variability of vegetative morphology and difficulties to see essential floral and fruit charac-

\footnotetext{
${ }^{1}$ Laboratory of Phytogeography and Applied Geobotany, Department DPTA, University of Rome Sapienza, via Flaminia 72, 00196 Rome, Italy, d.iamonico@yahoo.it
} 
ters have resulted in misinterpretations of names and misidentifications.

The aim of this work is to provide clarity to the taxonomy, morphology and ecology and revise the chorology of the species in Italy as a part of the treatment of Chenopodicaceae for the new Flora of Italy, Ed. S. Pignatti (see e.g. Iamonico 2009, 2010, 2011a, 2012a, 2013, Iamonico \& Kadereit 2012, Iamonico \& Sukhorukov 2013).

\section{MATERIALS AND METHODS}

The present study is based on an extensive analysis of literature (protologues included), personal field investigations (specimens collected by the author are preserved in the Herbarium Flaminio, HFLA), examination of herbarium material from $\mathrm{AO}, \mathrm{FI}, \mathrm{RO}$ and TR and checking of images of Linnean specimens, available on the web at Linnean Society Collections Online 2009). The nomenclature follows Conti et al. (2005) and Iamonico (2012b). The descriptions are based on Italian material and personal observations.

\section{RESULTS AND DISCUSSION}

\section{Notes ON TAXONOMY AND MORPHOLOGY}

Oxybasis chenopodioides was first described as $B l i$ tum chenopodioides by Linnaeus (1771) "... in Tataria; nunc in Suecia". Hiitonen (1933) proposed subgeneric rank for Blitum L. under Chenopodium. Aellen (1933) proposed the new combination Chenopodium chenopodioides (L.) Aellen ( $\equiv B l i$ tum chenopodioides L.), and discussed the affinity of the species with the related $C$. crassifolium Hornem. and C. rubrum, the first one considered a synonym of $C$. chenopodioides. As regard the relationship with C. rubrum, Aellen (1933) examined the photograph of two Linnaean specimens (Nos. 14.3 and 14.4, both received by Linnaeus from Arduino and labelled as "tataricum"), concluding that the original description was not written on the basis of these specimens because of the disharmony between their characters and the original description. He also supposed that the sheets could represent the taxon called $C$. rubrum. Problems and doubts of the correct application and typification of the name $B$. chenopodioides led some authors (e.g. Brenan 1964) to use the next safe name: $C$. botryodes $\mathrm{Sm}$. The Italian floras (e.g. Fiori 1923, Zangheri 1976, Pignatti
1982, Conti et al. 2005) always accept C. botryodes (sometimes $C$. chenopodioides doubtfully indicated in synonymy). On the basis of an extensive discussion, Uotila (2001a) removes the possibility that the name $C$. chenopodioides might be a synonym of $C$. rubrum, and a neotype was designated. Currently, the name $C$. chenopodioides was accepted in several important works (e.g. Akeroyd 1993, Uotila 1990, 2001b, Clemants \& Mosyakin 2003, Zhu et al. 2003). On the basis of recent molecular studies, Fuentes-Bazan et al. (2012a) recently resurrected the genus Oxybasis and proposed the new combinations $O$. chenopodioides and $O$. rubra.

On the basis of the protologues (Linnaeus 1753, 1771), O. chenopodioides and O. rubra differ in the tepals features: connate nearly to tip [Linnaeus (1771) reported "Calix ... concavus, connivens..."] and free or connate only at base, respectively. Other characters [shape of the leaves (subtriangular vs. subrhomboidal) and margins (entire or slightly toothed with obtuse tooths vs. toothed with acute tooths)] were often considered as diagnostic, but they partially overlap (Uotila 2001). In the Italian specimens the only constant diagnostic character is the difference in the tepals. As to the leaves, they are usually subtringular with entire margins (sometimes coarsely toothed with obtuse tooths) and with truncate base in $O$. chenopodioides, while subrhomboidal with toothed margins (tooths acute or acuminate with tip to distal part of the blade) and cuneate base in O. rubra. A further diagnostic character can be seen in the field: O. chenopodioides is usually prostrate and $O$. rubra erect (Table 1 ).

Oxybasis chenopodioides (L.) S. Fuentes, Uotila \& Borsch, Willdenowia 42: 15 (2012)

Bas.: Blitum chenopodiodes L., Mant. Pl. Altera: 170 (1771) - Type (designated by Uotila 2001: 95-96): Russia, Republic of Dagestan, XIX century, C. Steven s.n. (neotype H-1037202).

$\equiv$ Chenopodium chenopodioides (L.) Aellen, Ostenia, Festschr. Osten.: 98 (1903).

$\equiv$ Chenopodium botryoides Sm., Engl. Bot. 32, tab. 2247 (1811).

Description: Annual herb (therophyte), 5$50 \mathrm{~cm}$ tall. Stem usually prostrate or prostrateascending, reddish, glabrous (rarely slightly farinose), branched at the basal part. Leaf blade ovate, subtriangular $(2-4 \times 4-7 \mathrm{~cm})$, entire (sometimes with 1 basal tooth on both sides) or sometimes (distal leaves) irregularly toothed with ob- 
Table 1: Diagnostic characters between Oxybasis chenopodioides and O. rubra.

Tabela 1: Razlikovalni znaki med vrstama Oxybasis chenopodioides in O. rubra.

\section{Oxybasis chenopodioides}

Tepals of lateral flowers connate almost to tip

Leaf blade subtriangular, entire (somentimes with 1 basal tooth on both sides) or somentimes (distal leaves) irregularly toothed with obtuse teeth and truncate base

Plants usually prostrate or prostrate-ascending

tuse tooths, stalked (petiole $1-4 \mathrm{~cm}$ ), slightly succulent, often reddish; base truncate, apex obtuse. Floral glomerules arranged in terminal and/or lateral spike-like inflorescences; flowers dimorphic: terminal flowers bisexual, with 5 tepals; lateral flowers bisexual and/or female, usually with 3 tepals (tepals always connate nearly to tip); fruit covered by the tepals, with one seed, usually vertical, brown, shiny (diameter $0.6-0.8 \mathrm{~mm}$ ). $2 \mathrm{n}=18$ (Uotila 1990).

Vegetation and ecology: O. chenopodioides prefers to colonize habitats characterized by a seasonal cycle of submersion (mainly during the

\section{Oxybasis rubra}

Tepals of lateral flowers connate halfway or less

Leaf blade subrhomboidal, toothed with acute or acuminate teeth (rarely entire) and base cuneate
Plants erect

winter, with rain) and emersion (during the summer and autumn). The life cycle is short, 2-3(-4) months between August and November, and is completed during the submersion phase. Soil is humid, scarcely evoluted, scarcely structured and with a fine texture (pers. obs.). O. chenopodioides frequently grows along sandy coastal habitats near the sea level, even though (for example in Sardinia; see Iamonico \& Calvia 2010) it may be also found far from the coast line, up to 160-180 $\mathrm{m}$ a.s.l. (Fig. 1). During the later summer, $O$. chenopodioides can be often found from halophilous vegetation communities ascribed to the class

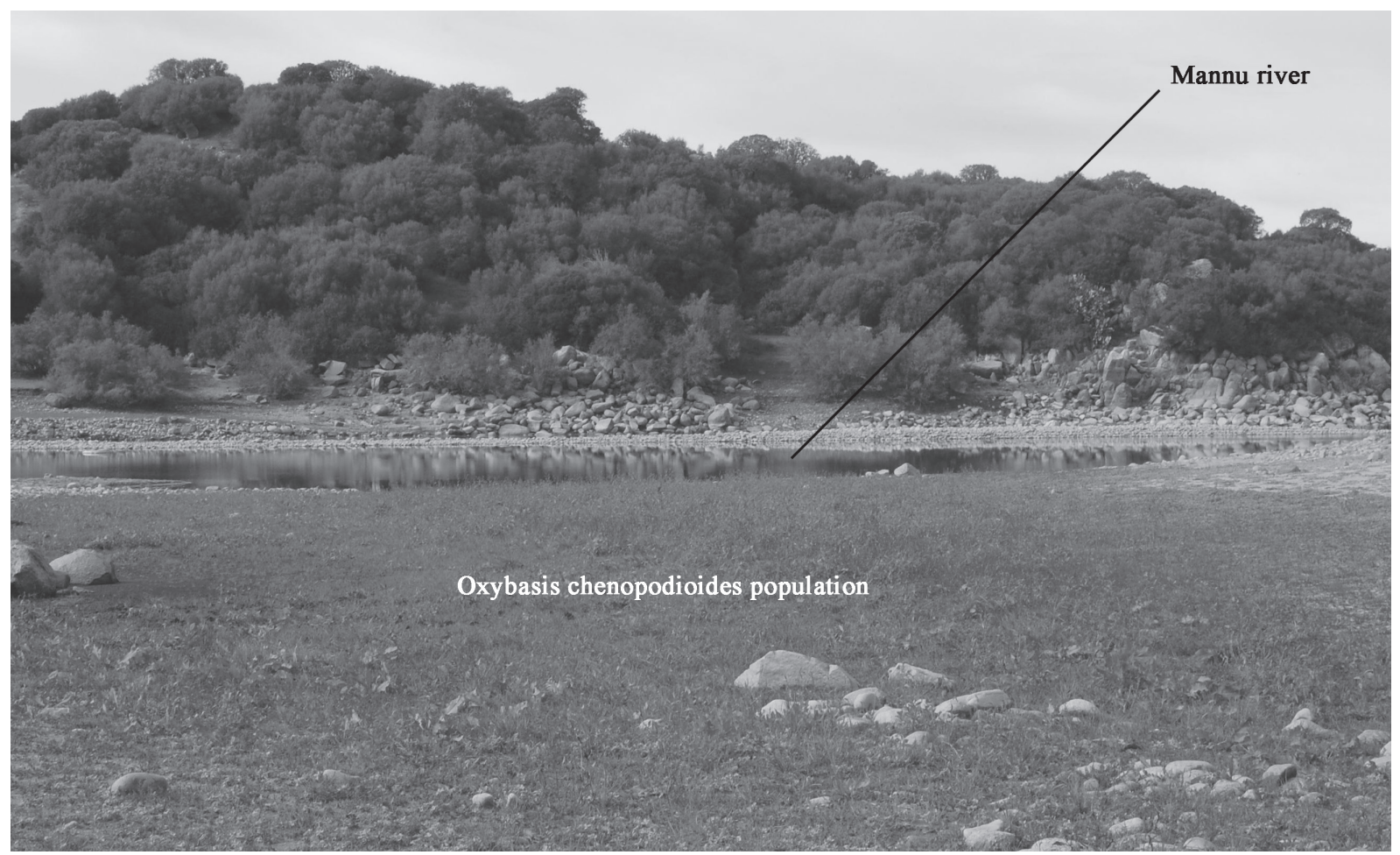

Figure 1: Oxybasis chenopodioides population along the Manu river (near Lake Coghinas), at locality Muros, in Olbia-Tempio Province of Sardinia. Photo by G. Calvia.

Slika 1: Populacija Oxybasis chenopodioides ob reki Manu (v bližini jezera Coghinas), lokacija Muros v provinci Olbia-Tempio, Sardinija. Foto: G. Calvia. 


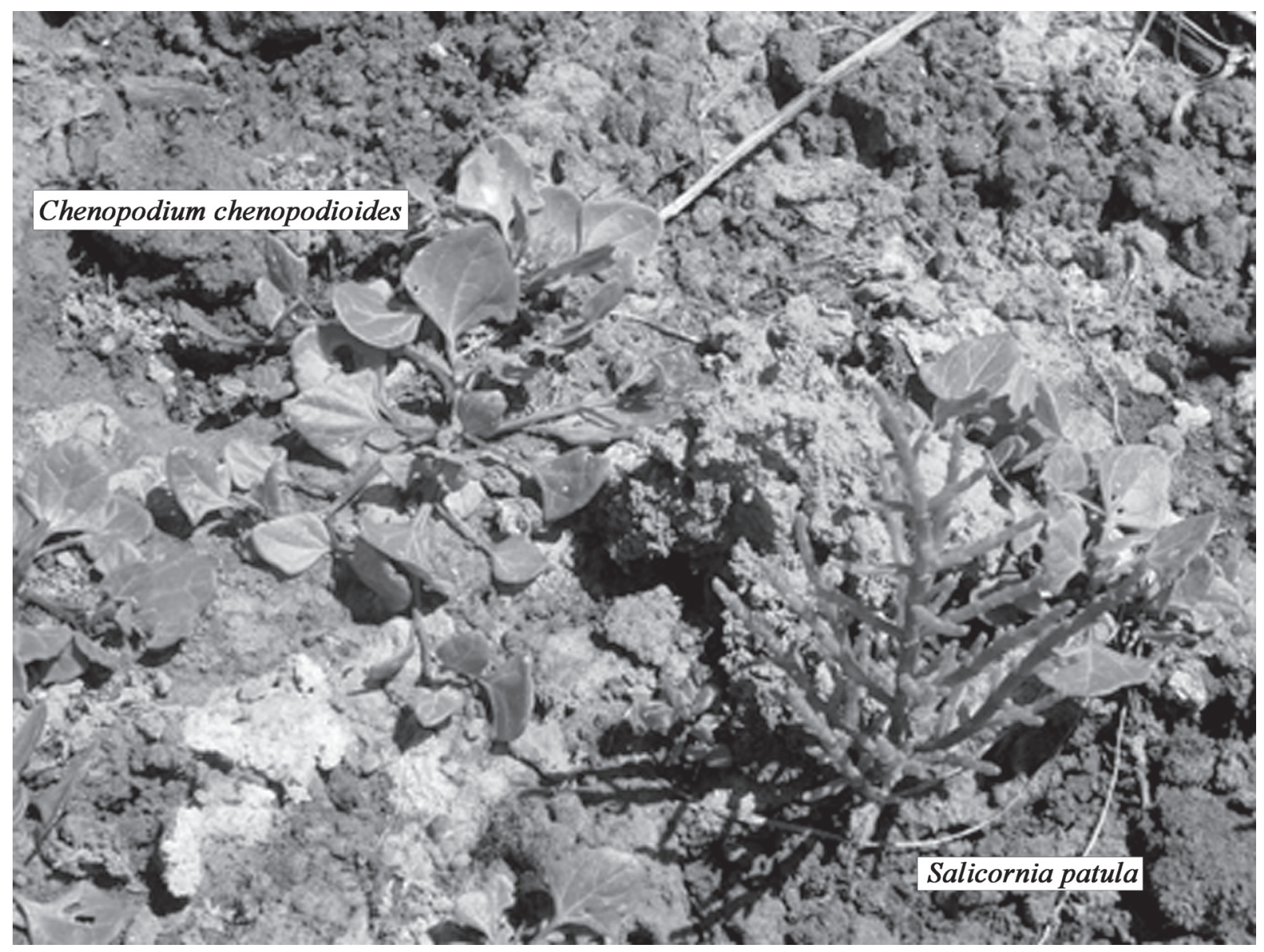

Figure 2: Oxybasis chenopodioides and Salicornia patula associated on shore of the Manu river in Delta del Po Park, EmiliaRomagna Region of Ravenna Province, north-eastern Italy. Photo by S. Montanari.

Slika 2: Oxybasis chenopodioides in Salicornia patula na obali reke Manu v delti reke Pad, regija Emilia-Romagna, provinca Ravenna, severovzhodna Italija. Foto: S. Montanari.

Thero-Salicornietea, order Thero-Salicornietalia (for example, in Emilia-Romagna region; see Iamonico \& Montanari 2010); the phytocenoses are characterized by the dominance of $O$. chenopodioides, Suaeda maritima. and Salicornia patula (Fig. 2). O. chenopodioides can be considered a halo-nitrophilous species.

General Distribution: Oxybasis chenopodioides is distributed in Europe, central and south-western Asia, northern Africa, and North America (Clemants \& Mosyakin 2003, Zhu et al. 2003, Uotila 2011).

Occurrence in Italy: Earlier Oxybasis chenopodioides has been recorded in the Regions of Friuli-Venezia Giulia, Veneto, Lazio and Campania (Conti et al. 2005), but it was found recently from four further Regions: Emilia-Romagna (Iamonico \& Montanari 2010), Sardina (Iamonico \& Calvia 2010), Puglia (Iamonico 2011b) and Toscana (Iamonico et al. 2013). Concerning the Lombardia region (northern Italy) Pignatti (1982) reported "Chenopodium botryoides ... lit. ... raram. all'interno (Bergam.)" (= "Chenopodium botryoides ... coasts ... rarely in the inland (Bergamo)") and probably referred to Fiori and Paoletti (1898, who reported "Quà e la nel Bergamasco ..."), Fiori (1923) (who reported "Bergam.") and Rodegher \& Venanzi (1894). The same record was also published by Martini (2012) in the Flora Vascolare della Lombardia centro-orientale (= Vascular Floras of the central-eastern Lombardia). These authors also indicated another station in Bergamo province (along the Brembo river) on the basis of D'auria \& Zavagno (1995). Conti et al. (2005) recently excluded $O$. chenopodioides (sub Chenopodium botryoides) from Lombardia ["segnalata in precedenza per errore" ("recorded in the past by mistake")] considering the species as casual (G. 
Galasso, personal communication). In fact, there are not clear reasons to consider O. chenopodioides as alien species for Bergamo province. This species naturally occurs in humid areas (both coastal and inland) of Europe, Asia and North Africa and it can be considered autochtonous for Italy. The discover by D’Auria \& Zavagni (1995) along the riverbanks of the Brembo river allows to hypotize that $O$. chenopodioides is authoctonous for the Bergamo territory. We found at FI one specimen collected in locality "Valle di Sermide" (Mantova Province, Lombardia Region) in the XIX century (ante 1842) sub Ch. rubrum and previously revised (1977) by P. Uotila. We confirmed (D. Iamonico, January 2010) the determination by Uotila, so highlighting for the first time the occurrence fo this species in the Province.

Finally, the Herbarium examination allowed also to found one specimen in FI (sub Ch. melanospermum) collected in the XIX century (ante Dec 1866) in Messina Province (Sicily) in locality "Murtiddi". We confirmed (D. Iamonico, January 2008) the previous determination by P. Uotila (1977) (see the final specimen list). O. chenopodioides was not indicated in the recent Catalogue of plants growing in Sicily (Giardina et al. 2007) and in the subsequent update (Raimondo \& Spadaro 2009). G. Domina (personal communication) confirms the absence of findings and literature data of the species for Sicily. Therefore, the specimen found reprensents a new floristic data for the region. Since the date of collection, it has to be considered as disappeared occerrence. At the current state of knowledge, we cannot know the real reasons for this apparent extinction. We know that the genus Chenopodium s. lat. is very poorly known and studied in Italy and that the urbanized areas (where several Chenopodium taxa grow) are less investigated then the natural ones (Iamonico 2009), so it is possible that further field investigations could allow to rediscover the taxon.

Oxybasis chenopodioides has a fragmented distribution in Italy and it can be considered rare. The main reason for this is the rarity of the habitat in which the specie occurs. These habitat are threatened by human activities (mainly tourism) that could cause the extition of $O$. chenodopioides and other associated taxa. The extinction can be confirmed for the area named "Valli di Sermide" (Mantova Province, Lombardia region, northern Italy) where the habitat cannot be see nowday because of human recoveries (G. Galasso, personal communication).
List of Italian Regions and Provinces in which

O. chenopodioides occurs (Fig. 4a):

- Friuli-Venezia Giulia: Udine (Pospichal 1897, Gortani \& Gortani 1905, sub C. botryoides);

- Veneto: Rovigo (Benetti \& Marchiori 1995, Masin et al. 2009, sub C. botryoides);

- Lombardia: Bergamo (Rodegher \& Venanzi 1894, Fiori 1923, sub C. rubrum $\beta$-botryoides, Pignatti 1982, sub C. botryoides, D'Auria \& Zavagno 1995, Martini 2012), Mantova (first record for the Province - see the final specimina list);

- Emilia-Romagna: Ravenna (Iamonico \& Montanari 2010);

- Toscana: Lucca (not recorded since 1861), Pisa (not recorded since 1862), Siena (Iamonico et al. 2013).

- Lazio: Latina, Roma (not recorded since 1920) (Anzalone et al. 2010, sub C. botryoides);

- Campania: Napoli (Terracciano 1910, 1917, sub C. boryoides, Agostini 1956, sub C. boryoides, Motti \& Ricciardi 2005);

- Puglia: Foggia (Iamonico 2011b);

- Sardegna: Olbia-Tempio (Iamonico \& Calvia 2010);

- Sicily: Messina (first record for the region see final specimina list).

Oxybasis rubra (L.) S. Fuentes, Uotila \& Borsch, Willdenowia 42: 15 (2012)

$\equiv$ Chenopodium rubrum L., Sp. Pl. 1: 218 (1753) Type (designated by Uotila 1993): Herb. Linnaeus 313.5 (lectotype LINN!).

$\equiv$ Blitum rubrum (L.) Rchb., Fl. Germ. Excurs. 2(1): 582 (1832).

Description: Annual herb (therophyte), 10$100 \mathrm{~cm}$ tall. Stem erect, green or \pm reddish, glabrous or nearly so, branched. Leaf blade ovate or lanceolate, subrhomboidal $(2.5-6 \times 4-8 \mathrm{~cm})$, toothed with teeths acute or acuminate (rarely entire), stalked (petiole 2-4 cm), sometimes slightly succulent, often red; base cuneate, apex acute. Floral glomerules arranged in terminal and/or lateral spike-like inflorescences; flowers dimorphic: terminal flowers bisexual, with 5 tepals; lateral flowers bisexual and/or female, usually with 3 tepals (tepals free or connate up to the middle at most); fruit with one seed, usually vertical, brown, shiny (diameter 0.6-1.1 mm). 2n = 18, 36 (Uotila 1990).

Vegetation and ecology: Oxybasis rubra mostly occurs in ruderal habitats and wastelands, at altitudes between $0-600 \mathrm{~m}$ a.s.l. It can be found in vegetation communities of the class Stellarietea 
mediae Tüxen, Lohmeyer \& Preising ex von Rochow 1951, order Chenopodietalia muralis Br.-Bl. 1936 (personal observation). Recently, the new association Polygono orientalis-Chenopodietum rubri (class Bidentetea tripartitae, order Bidentetalia tripartitae - Sciandrello 2009) was described from Sicily for phytocenoses that occur in habitat characterized by seasonel cycles of submersion (during the winter-spring period) and emersion (during the summer-autumn period) on clayey-muddy, nitrophilous and humid soils. O. rubra is a dominant species in this association. Floristic investigations (carried out in 2008) in Finale Ligure locality (Province of Savona in Liguria, northwestern Italy) also revealed that $O$. rubra grows in sandy coastal zone (Figure 3) potentially occupied by the association Salsolo kali-Cakiletum maritimae (Class Cakiletea maritimae, order Euphorbietalia peplis). O. rubra seems to have wider ecological demands than O. chenopodioides: it can colonize both synanthrophic habitats (mostly open wastelands with low soil humidity) and riverbanks (with humid soils also during the emersion phase). The species can be considered nitrophilous or hygro-nitrophilous.

General Distribution: Oxybasis rubra is distributed in Europe (mainly in Central territories, while it is rare in the Mediterranean area and it does not occurs in the the extreme east and north territories), central and south-western Asia, and in North America (Clemants \& Mosyakin 2003, Zhu et al. 2003, Uotila 1990, 2011). The occurrence in Italy has a general interest because of the rarity of this species in the Mediterranean area (see e.g. Jalas \& Suominen 1980, Greuter et al. 1984).

Occurrence in Italy: Oxybasis rubra was reported from nine Regions, Friuli-Venezia Giulia, Veneto, Trentino-Alto Adige, Lombardia, Liguria, Emilia-Romagna, Toscana, Abruzzo, Campania and Basilicata by Conti et al. (2005), and recently from two more, Valle d'Aosta by Pistarino et al. (2010) and Puglia by Iamonico \& Dura (2013) and it is mentioned but not confirmed from Umbria (Iamonico in press). In the past the species was recorded by mistake from Lazio (Iamonico \& Iberite 2008) and Sardegna Regions (Conti et al. 2007). Recent floristic surveys (January 2008) allowed to confirm the presence of $O$. rubra in Savona Province (locality Finale Ligure), where no record is known since the 1980s (G. Barberis, personal communication).

Oxibasis rubra has a wider distribution in Italy than $O$. chenopodioides since it appears to have a

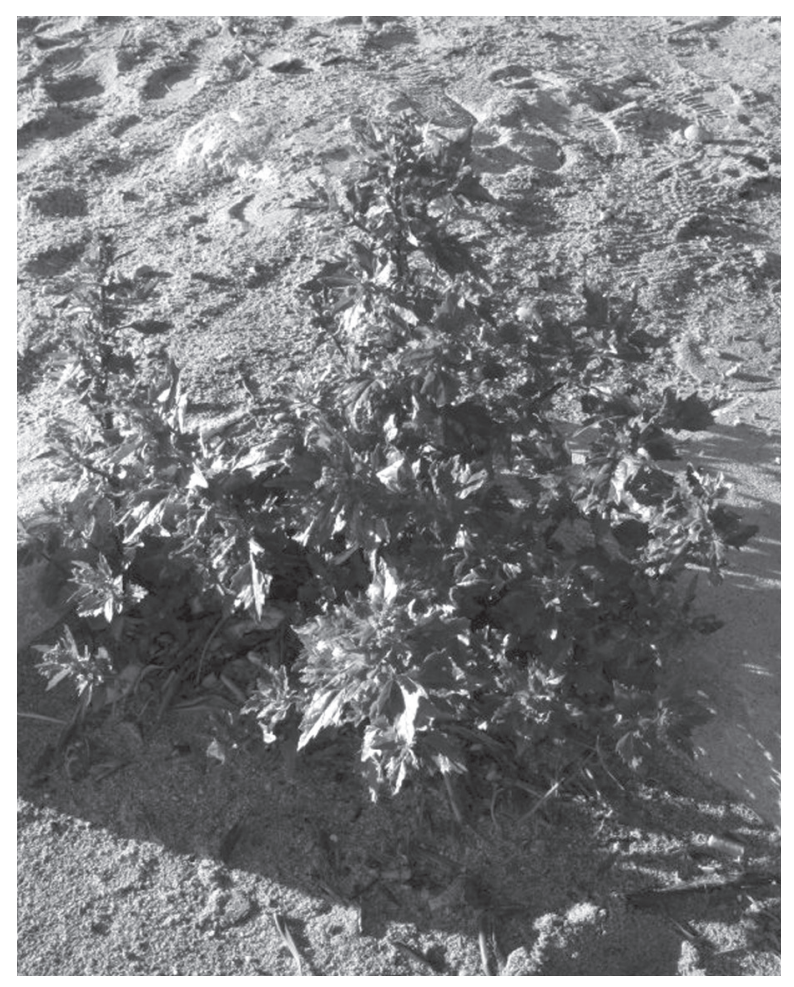

Figure 3: Oxybasis rubra in sandy substrate in Savona Province of Liguria Region, north-western Italy. Photo by D. Longo.

Slika 3: Vrsta Oxybasis rubra na peščeni podlagi v province Savona $\mathrm{v}$ regiji Liguria, severozahodna Italija. Foto: D. Longo.

larger ecological demand, also colonizing ruderal habitats at altitudes uop to $600 \mathrm{~m}$ a.s.l. However, its distribution is fragmented, especially in central and southern Italy. The species can be considered common in northern Italy, and less frequent in central and southern Italy.

List of Italian Regions and Provinces in which O. rubra occurs (Fig. 4b):

- Friuli-Venezia Giulia: Gorizia (Pospichal 1897, Poldini 2002, 2009), Pordenone (Poldini 2002), Trieste (Marchesetti 1896, Mazzena \& Polli 1982), Udine (Poldini 2002);

- Veneto: Belluno (Argenti \& Lasen 2004), Padova (Masin \& Tietto 2005, 2006), Vicenza (Curti \& Scortegagna 1998), Verona (Bianchini 1976);

- Trentino-Alto Adige: Bolzano (Wilhalm et al. 2006), Trento (Prosser 1995);

- Lombardia: Bergamo (Pignatti 1982);

- Piemonte: Alessandria (Iamonico \& Soldano 2012b);

- Valle d'Aosta: Aosta (Pistarino et al. 2010); 

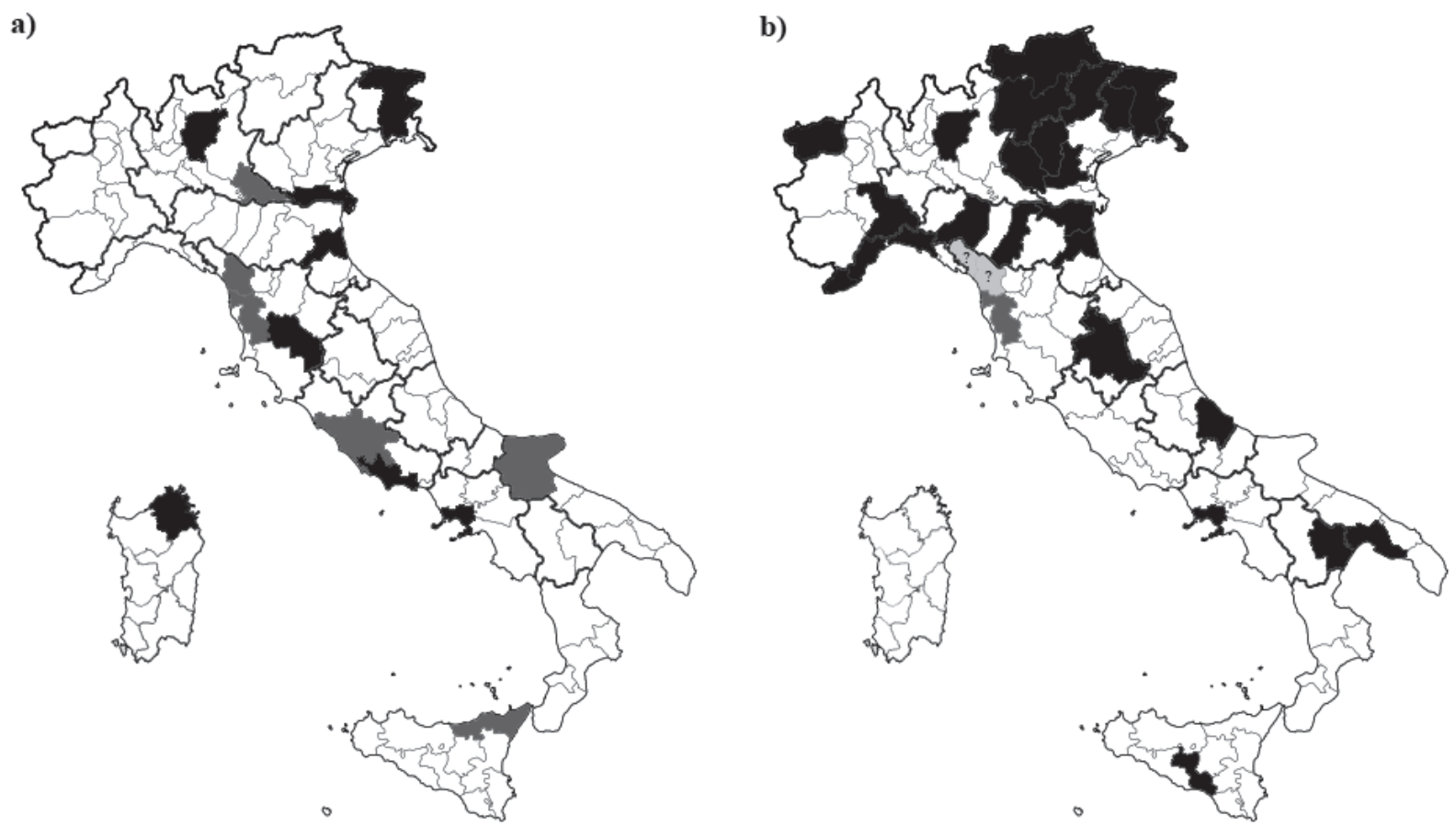

Figure 4: Distribution map of Oxybasis chenopodioides (a) and Oxybasis rubra (b) in Italy according to Provinces. Provinces with present records are marked in black, old records in gray and doubtful records in light gray with question marks.

Slika 4: Karte razširjenosti vrst Oxybasis chenopodioides (a) in Oxybasis rubra (b) v provincah Italije. Province z novimi podatki so označene s črno, stari podatki so predstavljeni s sivo in vprašljivi podatki s svetlo sivo in vprašajem.

- Liguria: Genova (Bertoloni 1804), Imperia (L. Aita et G. Barberis, personal communication) and Savona (in this latter Province the species is confirmed in the locality Finale Ligure).

- Emilia-Romagna: Ferrara (Beguinot 1910, Zavatti 1999-2000), Modena (Delfini 2003, Alessandrini et al. 2010), Parma (Ghilliani et al. 2004, Petraglia et al. 2005, Ghilliani 2010), Ravenna (Zangheri 1966, Lazzari et al. 2007, Bassi 2004);

- Toscana: Lucca [Montelucci (1964) reported “...'specialmente in base alla verticalità dei semi' e che forse si avvicinano alla var. botryoides (Sm.) Fiori" (“... 'especially based on the vertical seeds' that are maybe similar to the var. botryoides (Sm.) Fiori"), so the species can be considered doubt for this province), Massa-Carrara (Ferrarini \& Marchetti (1994) indicated a question mark, so the species is to be considered doubt), Pisa (Caruel 1860, Baroni 1897-1908);

- Umbria: Perugia (Bencivenga et al. 1977-1978, Iamonico in press);

- Abruzzo: Chieti (Leporatti et al. 2001a, 2001b);

- Campania: Napoli (Tenore 1823, 1831, Motti \& Ricciardi 2005);
- Puglia: Taranto (Iamonico in press, Iamonico \& Dura 2013);

- Basilicata: Matera (Gavioli 1947);

- Sicilia: Caltanissetta (Giardina et al. 2007, Sciandrello 2009).

\section{ACKNOWLEDGEMENTS}

Thanks are due to Directors and Curators of all quoted Herbaria for their support during my visits, loans of specimens/photographs or requests for information. I am also greatful to A. Alessandrini (Bologna), C. Argenti (Belluno), P. V. Arrigoni (Firenze), G. Barberis (Genova), F. Conti and F. Bartolucci (Barisciano), E. Del Guacchio (Salerno), G. Galasso and E. Banfi (Milano), M. Iberite (Latina), F. Prosser (Rovereto), A. Soldano (Vercelli), M. Vidali (Trieste) and T. Wilhalm (Bolzano) for information on the distribution. I thank my friends G. Calvia (Berchidda), D. Longo (Genova) and S. Montanari (Pangipane) for the permission to reproduce their photographs. Finally, I am greatful to P. Uotila and the other anonymous reviewer for the constructive comments. 


\section{REFERENCES}

Aellen, P. L. 1933: Nomenklatorische Bemerkungen zu einigen Chenopodien. Ostenia, Festschr. Osten: 89-101.

Agostini, R. 1956: Aster squamatus Hieron. nuova avventizia della flora campana. Delpinoa 9: 164.

Akeroyd, J. R. 1993: Chenopodium L. In: Tutin, T. G., Heywood, V. H., Burges, N. A., Moore, D. M., Valentine, D. H., Walters, S. M. \& Webb D. A. (eds.), Flora Europaea 1. Ed. 2. Cambridge University Press, Cambridge, pp. 111-114.

Alessandrini, A., Delfini, L., Ferrari, P., Fiandri, F., Gualmini, M., Lodesani, U. \& Santini, C. 2010: Flora del Modenese. Censimento, Analisi, tutela. ARTESTAMPA, Modena, 415 pp.

Anzalone, B., Iberite, M. \& Lattanzi, E. 2010: La flora del Lazio. Informatore Botanico Italiano 42(1): 187-317.

APG III 2009: An update of the Angiosperm Phylogeny Group classification for the orders and families of flowering plants: APG III. Botanical Journal of Linnean Society 161, 105-121.

Argenti, C. \& Lasen, C. 2004: Lista rossa della flora vascolare della Provincia di Belluno. Regione Veneto e Arpav, 152 pp.

Baroni, E. 1897-1908: Supplemento generale al "Prodromo della Flora Toscana di Teodoro Caruel". Ed. Soc. Bot. Ital., Firenze.

Bassi, A. 2004: Guida alla flora della Pineta San Vitale 2, Longo Editore, Ravenna, 400 pp.

Beguinot, A. 1910: Una escursione botanica nel littorale della Provincia di Ferrara. Bullettino della Società Botanica Italiana 9: 125-136.

Bencivenga, M., Cagnotti, M. R. \& Milletti, G. 1977-1978: La flora e la vegetazione spondicola e acquatica del fiume Nestore. Parte I: Flora. Annali della Facoltà di Agraria dell' Univeristà di Perugia 32(2): 499-522.

Benetti, G. \& Marchiori, S. 1995: Contributo alla conoscenza della flora vascolare del Polesine. Bollettino del Museo Civico di Storia Naturale di Verona 19(1992): 345-441.

Bertoloni, A. 1804: Plantae genuenses. Typis Societatis Aemulationis, Genuae, 145 pp.

Bianchini, F. 1976: Flora della Regione Veronese. Parte III. Spermatofite (Poligonali, Centrosperme). Bollettino del Museo Civico di Storia Naturale di Verona 3: 53-145.

Brenan, J. 1964: Chenopodium L. - In: Tutin, T. G., Heywood, V. H., Burges, N. A., Moore, D.
M., Valentine, D. H., Walters, S. M., Webb, D. A. (eds.), Flora Europea 1. Cambridge University Press, Cambridge, p. 94.

Caruel, T. 1860: Prodromo della Flora Toscana. Ed. Le Monnier, Firenze, 767 pp.

Clemants, S. E. \& Mosyakin, S. L. 2003: Chenopodium L. In: Flora of North America Editorial Committee (eds.), Flora of North America North of Mexico 4. Oxford University Press, New York \& Oxford, pp. 175-299.

Conti, F., Abbate, G., Alessandrini, A. \& Blasi, C. (eds.) 2005: An annotated checklist of the Italian vascular flora. Palombi \& Partner, Roma, 420 pp.

Conti, F., Alessandrini, A., Bacchetta, G., Banfi, E., Barberis, G., Bartolucci, F., Bernardo, L., Bonacquisti, S., Bouvet, D., Bovio, M., Brusa, G., Del Guacchio, E., Foggi, B., Frattini, S., Galasso, G., Gallo, L., Gangale, C., Gottschlich, G., Grünanger, P., Gubellini, L., Iiriti, G., Lucarini, D., Marchetti, D., Moraldo, B., Peruzzi, L., Poldini, L., Prosser, F., Raffaelli, M., Santangelo, A., Scassellati, E., Scortegagna, S., Selvi, F., Soldano, A., Tinti, D., Ubaldi, D., Uzunov. D. \& Vidali, M. 2007: Integrazioni alla checklist della flora vascolare italiana. Natura Vicentina (2006) 10: 5-74.

Curti, L. \& Scortegagna, S. 1998: Check-list delle piante vascolari della Provincia di Vicenza. Natura Vicentina 2: 3-46.

D'Auria, G. \& Zavagno, F. 1995: La vegetazione alveale del fiume Brembo, alla confluenza con l'Adda, in relazione a morfologia e substrato. Pianura, scienze e storia dell'ambiente padano, Cremona 7: 5-37.

Delfini, L., Fiandri, F., Lodesani, U. \& Santini, C. 2003: Contributo alla conoscenza della flora della provincia di Modena. Atti della Società dei Naturalisti e Matematici di Modena 134: 289-334.

Ferrarini, E. \& Marchetti, D. 1994: Prodromo alla flora della Regione Apuana. Parte prima (Lycopodiaceae - Leguminosae). Accad. Lunig. Sci. G. Capellini Editrice, La Spezia, 134 pp.

Fiori, A. 1923: Nuova Flora Analitica Italiana 1(3). Ed. M. Ricci, Firenze, 944 pp.

Fiori, A. \& Paoletti, G. 1898: Flora Analitica Italia 2. Tipografia del Seminario, Padova, 607 pp.

Fuentes-Bazan, S., Uotila, P. \& Borsch, T. 2012a: A novel phylogeny-based generic classification for Chenopodium sensu lato, and a tribal rearrangement of Chenopodioideae (Chenopodiaceae). Willdenowia 42: 5-24. 
Fuentes-Bazan, S., Mansion, G. \& Borsch, T. 2012b: Towards a species level tree of the globally diverse genus Chenopodium (Chenopodiaceae). Molecular Phylogenetics and Evolution 62: 359-374.

Gavioli, O. 1947: Synopsis Florae Lucanae. Nuovo Giornale Botanico Italiano 54: 78.

Ghilliani, L., 2010: Flora. Manuale pratico per conoscere la flora e gli ambienti del Parco del Taro. Collana Naturalistica del Parco del Taro, $1-5$.

Ghilliani, L., Grossi, M. \& Ottavini, L. 2004: Ricerca floristica su alberi e arbusti e erbe della Riserva Naturale Orientata Parma Morta. In: Associazione Pro Natura Parma (ed.), Alla scoperta di piante e fiori. Riserva Naturale Orientata Parma Morta, pp. 1-96.

Giardina, G., Raimondo F. M. \& Spadaro, V. 2007: A catalogue of plants growing in Sicily. Bocconea 50: 5-582.

Gortani, L. \& Gortani, M. 1905-1906: Flora friulana con speciale riguardo alla Carnia 1, Tip. Goretti, Udine, 519 pp.

Greuter, W., Burdet, H. \& Long, G. 1984: Medchecklist 1. Pteridophyta, Gymnospermae, Dicotyledones (Acanthaceae-Cneoraceae) 1. Conservatoire et jardin botaniques de la Ville de Genève, Genève.

Hiitonen, I. 1933: Suomen kasvio. Otava, Helsinki, $771 \mathrm{pp}$.

Iamonico, D. 2009: I generi Chenopodium e Dysphania in Italia (Amaranthaceae): stato attuale delle conoscenze. In: Peccenini, S. \& Domina, G. (eds.), Gruppi critici della Flora d'Italia. Tipolitrgrafia Euroservice Punto Grafica, Palermo, p. 13-14.

Iamonico, D. 2010: Confirmation of the occurrence of Chenopodium strictum subsp. strictum (Amaranthaceae s. 1.) in Italy. Phyton (Horn, Austria) 49(2): 235-240.

Iamonico, D. 2011a: Dysphania anthelmintica (Amaranthaceae), new to the non-native flora of Italy, and taxonomic considerations on the related species. Hacquetia 10(1): 41-48.

Iamonico, D. 2011b: Notula 1828. Chenopodium chenopodioides (L.) Aellen (Amaranthaceae). Notulae alla Checklist della flora italiana: 10. Informatore Botanico Italiano 43(2): 354.

Iamonico, D. 2012a: Studies on the genus Atriplex L. (Amaranthaceae) in Italy. II. Lectotypification of Atriplex elongata Guss. (Amaranthraceae). Candollea 67(1): 181-185.

Iamonico, D. 2012b: Notulae 1954-1957. Blitum
L., Chenopodiastrum S. Fuentes, Uotila \& Borsch, Lipandra Moq., Oxybasis Kar. \& Kir. Notulae nomenclaturali alla Checklist della flora italiana: 10. Informatore Botanico Italiano 42(2): 44(2): 398-399.

Iamonico, D. 2013a: Polycnemum verrucosum (Amaranthaceae), first record for the Italian native flora and comparison with related species $P$. arvense. Hacquetia 12(1): 5-9.

Iamonico, D. in press: Note floristiche per i generi Chenopodium L. e Dysphania R. Br. (Amaranthaceae) nell'Italia centro-meridionale. Archivio Geobotanico 12.

Iamonico, D. \& Calvia, G. 2010: Chenopodium chenopodioides (L.) Aellen (Amaranthaceae), specie nuova per la flora della Sardegna. Annali del Museo Civico di Rovereto, Sezione Archeologia, Storia, Scienze Naturali 25(2009): 141-147.

Iamonico, D., \& Dura, T. 2013: Notula. Oxybasis rubra (L.) S. Fuentes, Uotila \& Borsch (Chenopodiaceae). Notulae alla Checklist della flora italiana: 16. Informatore Botanico Italiano 45(2) (in press).

Iamonico, D. \& Iberite, M. 2008: Notula 1475. Chenopodium rubrum L. (Amaranthaceae). Notulae alla Checklist della flora italiana: 6. Informatore Botanico Italiano 40(2): 249.

Iamonico, D. \& Kadereit, G. 2012: Typification of the Name Kochia saxicola (Chenopodiaceae). Novon 22(4): 418-421.

Iamonico, D., Lastrucci, L. \& Viciani, D. 2013: Notula 1965. Oxybasis chenopodioides (L.) S. Fuentes, Uotila \& Borsch (Chenopodiaceae). Notulae alla Checklist della flora italiana: 15. Informatore Botanico Italiano 45(1): 95-96.

Iamonico, D. \& Montanari, S. 2010: Notula 1705. Chenopodium chenopodioides (L.) Aellen (Amaranthaceae). Notulae nomenclaturali alla Checklist della flora italiana: 9. Informatore Botanico Italiano 42(2): 517.

Iamonico, D. \& Soldano, A. 2012b: Notula 1901. Chenopodium rubrum L. (Amaranthaceae). Notulae alla Checklist della flora italiana: 13. Informatore Botanico Italiano 44(1): 179-180.

Iamonico, D. \& Sukhorukov, A. 2014: Studies on the genus Atriplex (Chenopodiaceae) in Italy. VI. Names by Michele Tenore: Atriplex axillaris, $A$. diffusa, and $A$. polysperma. Hacquetia 13(2): 297-302.

Jalas, J. \& Suominen, J. 1980: Atlas florae Europeae. Distribution of Vascular Plants in Europe 5. Helsinki University Printing House, Helsinki, 119 pp. 
Kadereit, G., Borsch, T., Weising, K. \& Freitag, H. 2003: Phylogeny of Amaranthaceae and Chenopodiaceae and the evolution of C4photosynthesis. International Journal of Plant Sciences 164: 959-986.

Kadereit, G., Gotzek, D., Jacobs, S. \& Freitag, H. 2005: Origin and age of Australian Chenopodiaceae. Organism Diversity and Evolution 5: 59-80.

Lazzari, G., Merloni, N. \& Spiani, D. 2007: Flora Punte Alberete-Valle Mandriole Parco Delta del Po - Emilia-Romagna. Quaderni dell'Ibis 1: 1-32.

Leporatti, M. L., Pavesi, A. \& Massari, G. 2001a: Contributo alla conoscenza della flora vascolare urbana di Chieti (Abruzzo). Webbia 56(2): 343-378.

Leporatti, M. L., Vincolato, L. \& Di Gioacchino, M. 2001b: Allergenic flora of Chieti town (Abruzzo, Central Italy). Preliminary observations. Allionia 37(2000): 210-216.

Linnean Society Collections Online 2009: The Linnean collections. http:// www.linnean-online.org/ (accessed 08 May 2013).

Linneaus, C. 1753: Species Plantarum 1. Laurentius Salvius, Stockholm, $560 \mathrm{pp}$.

Linneaus, C. 1771: Mantissa Plantarum Altera. Laurentius Salvius, Stockholm, 203 pp.

Marchesetti, C. 1896-97: Flora di Trieste e de' suoi dintorni. Tipografia del L. Austriaco, Trieste, $727 \mathrm{pp}$.

Martini, F. (ed.) 2012: Flora Vascolare della Lombaria centro-orientale 2: Atlante Corologico. Lint, Trieste, $328 \mathrm{pp}$.

Masin, R., Bertani, G., Cassanego, L., Favaro, G. \& Tietto, C. 2009: Indagini sulla flora vascolare del Delta veneto del Po e dei territori limitrofi (Italia Nord Orientale). Natura Vicentina 12(2009): 5-93.

Masin R. \& Tietto C. 2005: Flora dei Colli Euganei e della pianura limitrofa. Ed. Sapi, Padova, $136 \mathrm{pp}$.

Masin R. \& Tietto C. 2006: Flora Vascolare della Provincia di Padova (Italia Nord-Orientale). Natura Vicentina 9(2005): 7-103.

Mezzana, R. \& Polli, E., 1982: Gli stagni della Provincia di Trieste. Atti del Museo Civico di Storia Naturale di Trieste, 33: 1-216.

Montelucci, G. 1964: Ricerche sulla vegetazione dell'Etruria XIII. Materiali per la flora e la vegetazione di Viareggio. Webbia 19(1): 73-347.

Mosyakin, S. L. \& Clemants, S. E. 2002: New nomenclatural combinations in Dysphania R.
Br. (Chenopodiaceae): taxa occurring in North America. Ukrayins'k. Bot. Gelinrn. 59: 380-385.

Mosyakin, S. L. \& Clemants, S. E. 2008: Further transfer of glandular-pubescent species from Chenopodium subg. Ambrosia to Dysphania (Chenopodiaceae). Journal of the Botanical Research Institute of Texas 2(1): 425-431.

Motti, R. \& Ricciardi, M. 2005: La flora dei Campi Flegrei (Golfo di Napoli, Campania, Italia). Webbia 60(2): 407.

Petraglia, A., Tomaselli, M., Borghi, M.L., Cavozzi, C. \& Bolpagni, R. 2005: Flora e vegetazione della Riserva Naturale Orientata della Parma Morta (Italia Settentrionale). Acta Naturalia de "L'Ateneo Parmense" 41(1/2): 1-34.

Pignatti, S. 1982: Flora d'Italia 1. Edagricole, Bologna, $790 \mathrm{pp}$.

Pistarino, A., Forneris, G., Bovio, M., Matteucci, E., Pandolfo, G. \& Dal Vesco, G. 2010: L'Herbarium Alpium Occidentalium di Bruno Peyronel e Giovanna Dal Vesco: un contributo alla conoscenza della flora valdostana e piemontese. Museo Regionale di Scienze Naturali della Valle d'Aosta, Aosta, $552 \mathrm{pp}$.

Poldini, L. 2002: Nuovo atlante corologico delle piante vascolari nel Friuli Venezia Giulia. Reg. auton. Friuli Venezia Giulia. Azienda Parchi e Foreste reg., Univ. Studi Trieste, Udine, 529 pp.

Poldini, L. 2009: Guide alla Flora - IV. La diversità vegetale del Carso fra Trieste e Gorizia. Lo stato dell'ambiente. Le guide di Dryades 5 - Serie Florae IV (F - IV). Ed. Goliardiche, Trieste.

Pospichal, E. 1897-1899: Flora des österreichischen Küstenlandes 1, Franz Deuticke, Leipzig, Wien, 574 pp.

Prosser, F. 1995: Segnalazioni floristiche tridentine. IV. Annali del Museo Civico di Rovereto, Sezione Archeologia, Storia, Scienze Naturali 10(1994): 135-170.

Raimondo F. M. \& Spadaro, V. 2009: Addenda et emendanda to the "A catalogue of plants growing in Sicily". Flora Mediterranea 19: 303-312.

Rodegher, E. \& Venanzi, G. 1894: Prospetto della Flora della Provincia di Bergamo. Bergamo, Tipografia sociale.

Sciandrello, S. 2009: La vegetazione igrofila dei bacini artificiali della Provincia di Caltanissetta (Sicilia centro-meridionale). Informatore Botanico Italiano 41(1): 53-62.

Sukhorukov, A., Uotila, P., Zhang, M., Zhang, H.-X., Speranskaya, A.S., Krinitsyna, A.A. 2013: New combinations in Asiatic Oxybasis 
(Amaranthaceae s.l.): evidence from morphological, carpological and molecular data. Phytotaxa 144(1): 1-12.

Syme, T. B. 1811: English Botany or coloured figures of british plants, Plate 2247. R. Hardwicke, London, 549 pp.

Tenore, M. 1823: Florae Neapolitanae Prodromi Appendix Quarta. Ex Typographia Diarii Enciclopedici, Neapoli, $36 \mathrm{pp}$.

Tenore, M. 1831: Sylloge Plantarum Vascularium Florae Neapolitanae. Tipografia del Fibreno, Neapoli, 747 pp.

Terracciano, N. 1910: La Flora dei Campi Flegrei. Atii dell'Istituto di Incoraggiamento di Scienze Naturali di Napoli, Serie 6, 8: 1-336.

Terracciano, N. 1917: Aggiunta alla "Flora dei Campi Flegrei. Atii dell'Istituto di Incoraggiamento di Scienze Naturali di Napoli, Serie 7, 68(1916): 269-450.

Uotila, P. 1990: Chenopodium L. In: Castroviejo, S., Laínz, M., López Gonzáles, G., Monserrat, P., Muñoz Garmendia, F., Paiva, J. \& Villar, L. (eds.), Flora Iberica 2. Real Jardín Botánico, Madrid, pp. 484-500.

Uotila, P. 1993: Taxonomic and nomenclatural notes on Chenopodium in the Flora iranica area. Annales Botanici Fennici 30: 189-194

Uotila, P. 2001a: Taxonomic and nomenclatural notes on Chenopodium (Chenopodiaceae) for Flora Nordica. Annales Botanici Fennici 38: 95-97.

Uotila, P. 2001b: Chenopodium. In: Jonsell, B. (ed.) 2001: Flora Nordica 2. Swedish Royal Academy of Sciences, Stockolm, Sweden, pp. 4-31.

Uotila, P. 2011: Chenopodiaceae (pro parte majore). In: Euro+Med Plantbase - the information resource for Euro-Mediterranean plant diversity. http: / / ww2.bgbm.org/EuroPlusMed/ (last accessed 19 Nov 2013).

Verloove, F. \& Lambinon, J. 2006: The non-native vascular flora of Belgium: a new nothospecies and three new combinations. Systematics and Geography of Plants 76: 217-220.

Western Australian Herbarium 1998-2009: FloraBase - The Western Australian Flora. Department of Environment and Conservation. http://www.florabase.dec. wa.gov.au/ (last accessed 08 May 2013).

Wilhalm, T., Niklfeld, H. \& Gutermann, W. 2006: Katalog der Gefäßpflanzen Südtirols. Veröffentlichungen des Naturmuseums Südtirol Nr. 3. Folio Verlag, Wien-Bozen.
Zangheri, P. 1966: Repertorio della flora e fauna della Romagna. Museo Civico di Storia Naturale di Verona, Verona, $2173 \mathrm{pp}$.

Zangheri, P. 1976: Flora Italica 1. Ed. Cedam, Padova, $1157 \mathrm{pp}$.

Zavatti, E. 1999-2000: Indagini sulla vegetazione delle cave per l'estrazione di materiali inerti del Ferrarese. Tesi di Dottorato, Università degli Studi di Ferrara, Ferrara.

Zhu (Chu), G., Mosyakin, S. L. \& Clemants, S. E. 2003: Chenopodium L. In: Wu, Z. Y., Raven, P. H. \& Hong, D. Y. (eds.): Flora of China, 5. St. Louis: and Missouri Botanical Garden Press, Beijng, pp. 378-384.

\section{APPENDIX}

Selected specimens seen.

Oxybasis chenopodioides (L.) S. Fuentes, Uotila \& Borsch - ITALY: Emilia-Romagna. Ravenna, Parco Delta del Po, Pineta di San Vitale, bassura tra le paleodune (a nord del canale "Viacerba"), $0 \mathrm{~m}$ a.s.l., 20 Sep 2009, Leg. S. Montanari, Det. D. Iamonico et S. Montanari (FI, Herb. Iamonico). Lazio. Latina, Circeo, Lago di Fogliano, depressioni retrodunali inondate, $0 \mathrm{~m}$ a.s.l., 1997, leg. M. Iberite (FI, RO, Herb. M. Iberite). Lombardia. Mantova, Valle di Sermide, XIX century (ante 1842), sine coll. (sub Ch. rubrum), rev. P. Uotila (1977), conf. D. Iamonico (08 Jan 2010) (FI). Puglia. prope Cerignola, in argillosis inundatis abulia, XIX century (ante Apr 1851), sine coll. (sub Chenopodium sp.), rev. P. Uotila (1977), conf. D. Iamonico (08 Jan 2010) (FI). Sardegna. Oschiri (Olbia-Tempio province), lago Coghinas, loc. Muros, sabbie e fanghi vicino al ruscello, 162164 m a.s.l., 19 Nov 2006, leg. G. Calvia, det. D. Iamonico et G. Calvia (Herb. Iamonico); Berchidda (Olbia-Tempio province), loc. Silvani, Rio Mannu di Berchidda-Oschiri, fanghi e pietraie, 162-163 m a.s.l., 04 Nov 2009, leg. G. Calvia, det. D. Iamonico et G. Calvia (FI, Herb. Iamonico). Sicilia. Messina, ai Murtiddi, XIX century (ante Dec 1866), sine coll. (sub Ch. melanospermum), rev. P. Uotila (1977) (sub Ch. cfr. chenopodioides), conf. D. Iamonico (08 Jan 2010) (FI). Toscana. Lucca, palude di Massaciuccoli, 5 Sep 1861, leg. Beccari (sub Ch. rubrum $\beta$-crassifolium), rev. P. Uotila (1977), conf. D. Iamonico (08 Jan 2010) (FI); Pisa, Colmata di Tombolo, 10 Sep 1861, leg. Bec- 
cari (sub Ch. rubrum $\beta$-crassifolium), rev. P. Uotila (1977), conf. D. Iamonico (08 Jan 2010) (FI); Pisa, Macchia di Pisa in Tombolo, Sep 1862, leg. Beccari (sub Ch. rubrum), rev. P. Uotila (1977), conf. D. Iamonico (08 Jan 2010) (FI); Siena, lago di Chiusi, sponde fangose del lago, 20 Sep 2012, leg. L. Lastrucci, D. Viciani et R. Viganò, det. D. Iamonico et L. Lastrucci (FI).

Oxybasis rubra (L.) S. Fuentes, Uotila \& Borsch - ITALY: Campania. Napoli, Lago d'Agnano, 19-19-1870, sine coll. (RO). Liguria. Genova, alveo del torrente Polcevera contro la conceria in quel di Fegino (Borzoli), 30-09-1904, sine coll. (RO); Savona, Finale Ligure, Jan 2008, leg. L. Longo det. D. Iamonico s.n. (HFLA). Puglia. Taranto, spiaggia, 27-07-1905, sine coll. (RO). Trentino-Alto Adige. Trento, presso malghe, 08 (XIX sec.), leg. et det. Rabbi (sub Blitum virgatum L.), rev. F. Prosser 23-12-2009 (TR). Valle d'Aosta. Aosta, Hône, incolti sulla riva destra della Dora, 2010, $345 \mathrm{~m}$ a.s.l., leg. et det. M. Bovio et al, conf. D. Iamonico (AO). 